\title{
Novel quinazoline and pyrido[2,3-d]pyrimidine derivatives and their hydroselenite salts as antitumoral agents
}

\author{
Juan Antonio Palop ${ }^{a *}$, Daniel Plano ${ }^{\mathrm{a}, \mathrm{b}}$, Esther Moreno ${ }^{\mathrm{a}, \mathrm{c}}$, and Carmen Sanmartín ${ }^{\mathrm{a} *}$ \\ ${ }^{a}$ Department Organic and Pharmaceutical Chemistry. University of Navarra, Irunlarrea, 1 \\ E-31008 Pamplona, Spain. \\ ${ }^{b}$ Department of Pharmacology, Penn State Hershey Cancer Institute, Penn State Hershey \\ College of Medicine, CH72, 500 University Drive, Hershey, PA 17033, USA. \\ ${ }^{c}$ Tropical Health Institute. University of Navarra, Pío XII, 53, E-31008 Pamplona, Spain. \\ E-mail:jpalop@unav.es, sanmartin@unav.es
}

\section{Dedicated to Rosa M. Claramunt Vallespí on the occasion of her $65^{\text {th }}$ anniversary}

DOI: http://dx.doi.org/10.3998/ark.5550190.p008.244

\begin{abstract}
A series of 22 quinazolines, pyrido[2,3- $d]$ pyrimidines and their hydroselenite salts were synthesized with the aim of evaluating in vitro their cytotoxicity against PC-3 cell line and their antioxidant properties related to DPPH (1,1-diphenyl-2-picrylhydrazylradical) activity, showing some of them better profile than the respective controls. Three of these derivatives $(\mathbf{5 d}, \mathbf{6 d}$ and 7f) were selected in order to gain preliminary insights to establish the mechanism of action. Caspase-3 activity and cell cycle regulation studies revealed that compound $\mathbf{6 d}$ provoked an increase in caspase-3 level accompanied by cell cycle perturbation in a time-dependent manner.
\end{abstract}

Keywords: antioxidant, cytotoxicity, pyridopyrimidine, quinazoline, selenite.

\section{Introduction}

Although the development of novel targeted antitumor drugs have obtained important progress in recent years, cancer remains the major leading cause of death in the world due to drug resistance or undesirable toxic effects. Quinazoline derivatives have been utilized extensively in medicinal chemistry due to its privileged structure that shows various pharmacological activities, such as antifungal, ${ }^{1}$ antibacterial, ${ }^{2}$ anti-inflammatory, ${ }^{3}$ anticonvulsant ${ }^{4}$, antihypertensive ${ }^{5}$ and anticancer activities $^{6-8}$ among others. This scaffold has been identified as new class of cancer chemotherapeutic agents acting as potent inhibitors for epidermal growth factor receptor (EGFR), ${ }^{9}$ or dihydrofolate reductase. ${ }^{10}$ Furthermore, its ability to induce apoptosis, ${ }^{11,12}$ or 
modulate caspases $^{13}$ as well as its capacity to bind the DNA have also been reported. ${ }^{14}$ Moreover, the anticancer activity of photoactivable drugs containing the quinazoline moiety has been evaluated. ${ }^{15}$ On the other hand, pyrido[2,3-d]pyrimidine derivatives are of great interest due to their anticancer or antiproliferative activities. ${ }^{16-18}$ They exhibited very diverse biological profiles. Some members of this family inhibited tyrosine kinases ${ }^{19}$ whereas others inhibited nonreceptor tyrosine kinases such us PI3K and mTOR. ${ }^{20}$ Thus, pyridopyrimidine derivatives produced dihydrofolate reductase inhibition ${ }^{21}$ as well as cell cycle modulation. ${ }^{22}$

Selenium (Se) is an essential trace element that has been identified as an anticarcinogenic agent, with supporting evidence from epidemiological studies, clinical intervention trials, preclinical intervention studies (animal cancer models) and cell culture studies. Natural organic and inorganic sources of Se as well as synthetic organoselenium compounds have been shown to be effective and safe in the treatment and prevention of cancer. ${ }^{23-26}$

The observations outlined above, along with our experience in the synthesis and antitumoral studies related to quinazoline and pyrido[2,3- $d$ ]pyrimidines, ${ }^{27-31}$ so as a continuation with our efforts in the search of new selenium derivatives with antitumoral properties ${ }^{32-38}$ enthused us to develop new 2,4-disubstituted quinazoline and pyrido[2,3- $d$ ] pyrimidine derivatives. The linkages investigated were (-NH-), which was inserted in positions 2 and/or 4, and sulfur which was introduced in the 2-position. Bonded to these linkages, aliphatic chains of variable length with aryl rings at the end of the chain were placed. In addition, in the aryl rings different chemical functions that are present in a number of antineoplastic agents ${ }^{39-41}$ such as methylthio, methylseleno or selenocyanate were introduced in order to verify their possible influence on the biological activity. The choice of different or identical substituents in 2 and 4 positions was done with the aim of corroborating the importance of molecular symmetry in the biological activity. Many literature reports include molecules that possess symmetry as cytotoxic agents. ${ }^{42}$ Finally, to improve the low water solubility and bioavailability, that has limited the development of some of these compounds, some derivatives were formulated as hydroselenite salts.

All the derivatives were screened by cell viability assays against a human prostate cancer cell line (PC-3) and as antioxidants using the DPPH test. In order to gain preliminary insights related to the mechanism of action, some of the most promising compounds were also evaluated as caspase modulators and cell cycle regulators.

\section{Results and Discussion}

\section{Chemistry}

Schemes 1 and 2 outline the synthetic pathway used to obtain compounds described in this paper. In order to prepare these molecules, the most appropriate starting materials were some compounds which were prepared previously by us, such as 4-hydroxy-2-methylthioquinazoline $\mathbf{1}^{31}$ and 2-methylthio-4-oxo-3,4-dihydropyrido[2,3-d]pyrimidine $\mathbf{2}^{29}$ (Scheme 1) and the commercially available 2,4(1H,3H)-quinazolinedione A (Aldrich, 86-96-4) (Scheme 2) and the 
pyrido[2,3- $d$ ]pyrimidine-2,4(1H,3H)-dione B (Shanghai Richem International Co., Ltd) (Scheme 2).

The susbstituted 4-alkylamino-2-methylthio derivatives of quinazoline and pyrido[2,3$d$ ]pyrimidine have been synthesized in two steps (Scheme 1) starting from compounds $\mathbf{1}$ and $\mathbf{2}$, respectively. Upon refluxing with freshly distilled phosphoryl chloride $\left(\mathrm{POCl}_{3}\right)$ in presence of dimethylformamide (DMF), compounds $\mathbf{1}$ and $\mathbf{2}$ yielded the corresponding key 4-chloro intermediates $\mathbf{3}$ and $\mathbf{4}$, which were used without purification. Reaction of $\mathbf{3}$ and $\mathbf{4}$ with the appropriate amine in a molar ratio 1:1.1 respectively, in ethanol by refluxing gave the desired compounds 5a-5d in yields ranging from 4 to $60 \%$. Compounds 5a-5d were converted in hydroselenite salts (6a-6d) by reaction with selenium dioxide in heating in a mixture ethanol:water (1:1) (Scheme 1).

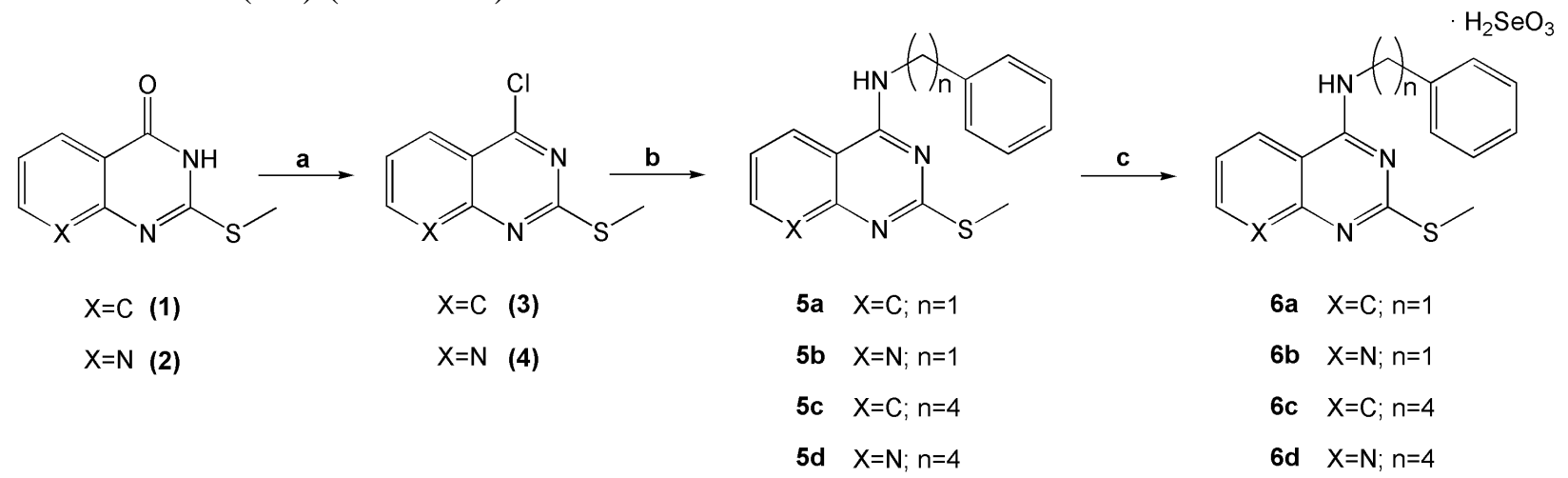

a: $\mathrm{POCl}_{3} / \mathrm{DMF}$; b: phenylalkylamine, EtOH; c: $\mathrm{SeO}_{2}, \mathrm{EtOH}: \mathrm{H}_{2} \mathrm{O}(1: 1)$.

Scheme 1. Synthetic routes for the preparation of compounds $5 \mathbf{a}-\mathbf{5} \mathbf{d}$ and $\mathbf{6 a - 6} \mathbf{d}$.

On the other hand, the commercially available compounds A or $\mathbf{B}$ (Scheme 2) reacted with phosphoryl chloride in the presence of DMF in one step to give the corresponding dihalides which were further reacted with the appropriated amines in ethanol using triethylamine (TEA) as catalist to afford the target compounds (7a-7h) with good yields. The corresponding salts (8a-8f) were obtained by treating selenium dioxide with the organic free bases quinazoline and pyridopyrimidine, respectively. Salts (6a-6d and 8a-8f) were characterized by a broad singlet in ${ }^{1}$ H NMR spectrum (Scheme 2). 


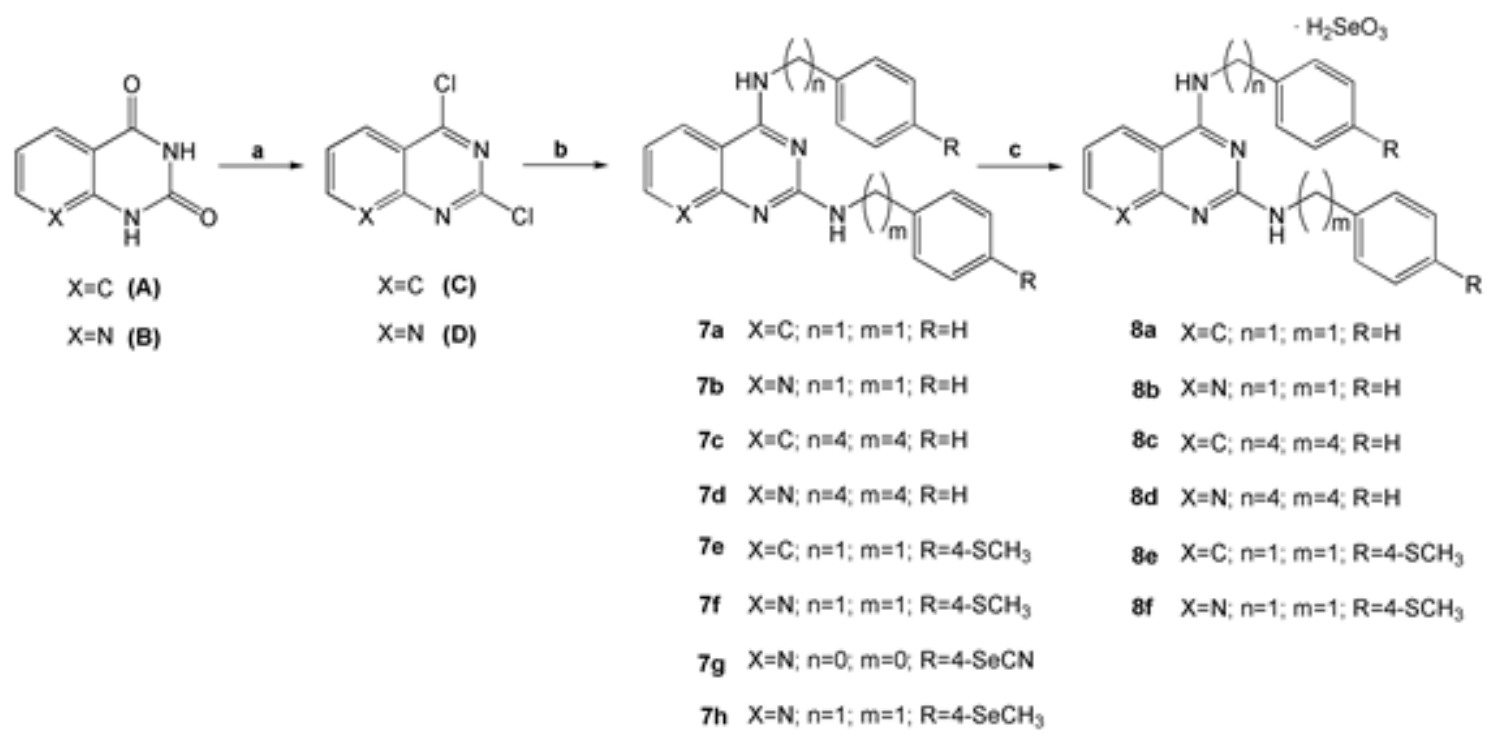

a: $\mathrm{POCl}_{3} / \mathrm{DMF}$; b: The corresponding amine, TEA, EtOH; c: $\mathrm{SeO}_{2}, \mathrm{EtOH}: \mathrm{H}_{2} \mathrm{O}$ (1:1).

Scheme 2. Synthetic route for the preparation of compounds $\mathbf{7 a - 7 h}$ and $\mathbf{8 a - 8 f}$.

\section{Biological Evaluation}

a) Cytotoxic activity in PC-3

Initially, the new compounds were evaluated for their in vitro cytotoxic activity against a human prostate cancer cell line (PC-3, ATCC, Manassas, VA) using the MTT assay. ${ }^{43}$ After an extensive literature review, this cell line was selected considering that many clinical trials suggest a role of some selenium compounds in the reduction of prostate cancer. ${ }^{44-46}$ Results are tabulated as $\mathrm{IC}_{50}$ values. $\mathrm{IC}_{50}$ was defined as the concentration of tested compound that cause $50 \%$ inhibition of cell growth, as compared to the untreated control. $\mathrm{IC}_{50}$ values were calculated by log-linear interpolation of data points. All experiments were independently performed at least three times and values calculated after 72 hours exposure (drug concentrations of 2, 5, 7 and 10 $\mu \mathrm{M})$. These concentrations have been chosen with an exigent criteria in order to select very potent compounds (with $\mathrm{IC}_{50}<10 \mu \mathrm{M}$ ). To place the data in perspective, topotecan and methylseleninic acid were selected as positive controls.

The results presented in Table 1 show that twelve compounds $5 \mathbf{d}, \mathbf{6 a}, \mathbf{6 c}, \mathbf{6 d}, \mathbf{7 b}, 7 \mathbf{e}, 7 \mathbf{f}, 7 \mathbf{h}$, $\mathbf{8 b}, \mathbf{8 c}, \mathbf{8 e}$ and $\mathbf{8 f}$ with $\mathrm{IC}_{50}<8 \mu \mathrm{M}$ are more potent than methylseleninic acid $\left(\mathrm{IC}_{50}=8.4 \mu \mathrm{M}\right)$ exhibiting seven of them $(\mathbf{6 a}, \mathbf{6 c}, 7 \mathbf{e}, \mathbf{7 f}, \mathbf{7 h}, \mathbf{8 e}$ and $\mathbf{8 f})$ higher cytotoxicity than topotecan $\left(\mathrm{IC}_{50}=\right.$ $4.0 \mu \mathrm{M})$. A detailed SAR analysis is not feasible taking into account the relatively small number of derivatives tested, but some observations and comparisons can be made. This primary screening reveals that the pyridopyrimidine nucleus is better than the corresponding quinazoline, mainly when the substituents in 2 and 4 positions are different. For example, if we compare derivatives $5 \mathbf{c}\left(\mathrm{IC}_{50}>10 \mu \mathrm{M}\right)$ with $\mathbf{5 d}\left(\mathrm{IC}_{50}=5.8 \mu \mathrm{M}\right)$ or compound 7a $\left(\mathrm{IC}_{50}>10 \mu \mathrm{M}\right)$ with $7 \mathbf{b}$ $\left(\mathrm{IC}_{50}=8.0 \mu \mathrm{M}\right)$. In contrast, for symmetrical derivatives $\mathbf{7 c}$ and $\mathbf{7 d}$, or $\mathbf{7 e}$ and $\mathbf{7 f}$ the activities are similar. Moreover, it has been confirmed that molecular symmetry improved the cytotoxic 
activity in comparison with non-symmetrical derivatives. For example, only four compounds $(\mathbf{5 d}, \mathbf{6 a}, \mathbf{6 c}$ and $\mathbf{6 d})$ of the non-symmetrical molecules (5a-5d and $\mathbf{6 a - 6 d})$ were active. However, from the rest of the tested derivatives (14), that presented molecular symmetry, ten of them showed activity. The length of the alkylamino side chains is not crucial for the cytotoxicity when the linkages inserted in positions 2 and 4 are identical. Compounds $7 \mathbf{a}(\mathrm{m}=1)$ versus $\mathbf{7 c}(\mathrm{m}=4)$ indicated that the cytotoxicity may not be affected by the length of alkyl substituents. Another aim of this study was to test the importance of the presence of hydroselenite salt in the formulation. Previously, some studies of Arsenyan et al. ${ }^{47-49}$ have reported the cytotoxic activity against hepatoma, fibrosarcoma, melanoma, neuroblastoma of some heterocycles formulated as hydroselenites. Taking into account the above aforementioned we concluded that the effect of hydroselenite salts formulation depends of the central scaffold. So, hydroselenite salts enhanced the cytotoxicity of quinazoline heterocycle framework compounds: $\mathbf{5 a}$ versus $\mathbf{6 a}, \mathbf{5 c}$ versus $\mathbf{6 c}$, $7 \mathbf{a}$ versus $\mathbf{8 a}, \mathbf{7 c}$ versus $\mathbf{8 c}$ but they do not modified it or have a weak effect in pyridopyrimidine derivatives: $\mathbf{5 b}$ versus $\mathbf{6 b}, \mathbf{5 d}$ versus $\mathbf{6 d}, \mathbf{7 b}$ versus $\mathbf{8 b}$.

The presence of substituents $\mathrm{SCH}_{3}$ or $\mathrm{SeCH}_{3}$ located at para position of the aryl moiety improved the cytotoxicity independently of the formulation as salt or of the central scaffold. This point is corroborated by the fact that if we compared the activities of 7e, 7f, 7h, 8e, and 8f, they are similar ( $\mathrm{IC}_{50}$ from 1.5 to $3.2 \mu \mathrm{M}$ ). To our surprise, $7 \mathbf{g}$ with $\mathrm{SeCN}$ group at para position did not show as marked cytotoxic activity on this cell line $\left(\mathrm{IC}_{50}=9.4 \mu \mathrm{M}\right)$. This fact may be due to the replacement of the flexible aliphatic side chains $(n$ and $m=1)$ by a rigid chain $(n$ and $m=0)$.

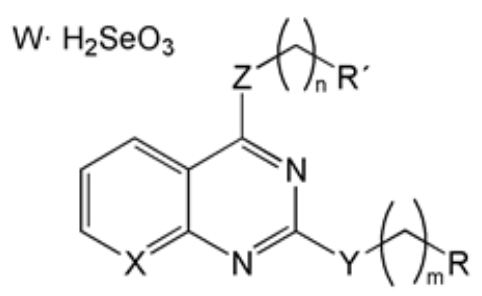

Table 1. Cytotoxic activity of compounds in PC-3 cell line

\begin{tabular}{cccccccccc}
\hline Comp. & $\mathbf{X}$ & $\mathbf{Y}$ & $\mathbf{m}$ & $\mathbf{R}$ & $\mathbf{Z}$ & $\mathbf{n}$ & $\mathbf{R}^{\prime}$ & $\mathbf{W}$ & $\mathbf{I C}^{\mathbf{a} 50}(\boldsymbol{\mu M})$ \\
\hline $\mathbf{5 a}$ & $\mathrm{C}$ & $\mathrm{S}$ & 0 & $\mathrm{CH}_{3}$ & $\mathrm{NH}$ & 1 & $\mathrm{C}_{6} \mathrm{H}_{5}$ & 0 & $>10$ \\
$\mathbf{5 b}$ & $\mathrm{N}$ & $\mathrm{S}$ & 0 & $\mathrm{CH}_{3}$ & $\mathrm{NH}$ & 1 & $\mathrm{C}_{6} \mathrm{H}_{5}$ & 0 & $>10$ \\
$\mathbf{5 c}$ & $\mathrm{C}$ & $\mathrm{S}$ & 0 & $\mathrm{CH}_{3}$ & $\mathrm{NH}$ & 4 & $\mathrm{C}_{6} \mathrm{H}_{5}$ & 0 & $>10$ \\
$\mathbf{5 d}$ & $\mathrm{N}$ & $\mathrm{S}$ & 0 & $\mathrm{CH}_{3}$ & $\mathrm{NH}$ & 4 & $\mathrm{C}_{6} \mathrm{H}_{5}$ & 0 & 5.8 \\
$\mathbf{6 a}$ & $\mathrm{C}$ & $\mathrm{S}$ & 0 & $\mathrm{CH}_{3}$ & $\mathrm{NH}$ & 1 & $\mathrm{C}_{6} \mathrm{H}_{5}$ & 1.97 & 3.4 \\
$\mathbf{6 b}$ & $\mathrm{N}$ & $\mathrm{S}$ & 0 & $\mathrm{CH}_{3}$ & $\mathrm{NH}$ & 1 & $\mathrm{C}_{6} \mathrm{H}_{5}$ & 0.45 & $>10$ \\
$\mathbf{6 c}$ & $\mathrm{C}$ & $\mathrm{S}$ & 0 & $\mathrm{CH}_{3}$ & $\mathrm{NH}$ & 4 & $\mathrm{C}_{6} \mathrm{H}_{5}$ & 1.25 & 3.8 \\
$\mathbf{6 d}$ & $\mathrm{N}$ & $\mathrm{S}$ & 0 & $\mathrm{CH}_{3}$ & $\mathrm{NH}$ & 4 & $\mathrm{C}_{6} \mathrm{H}_{5}$ & 1 & 7.0 \\
\hline
\end{tabular}


Tabel 1 (continued)

\begin{tabular}{|c|c|c|c|c|c|c|c|c|c|}
\hline $7 \mathbf{a}$ & $\mathrm{C}$ & $\mathrm{NH}$ & 1 & $\mathrm{C}_{6} \mathrm{H}_{5}$ & $\mathrm{NH}$ & 1 & $\mathrm{C}_{6} \mathrm{H}_{5}$ & 0 & $>10$ \\
\hline $7 b$ & $\mathrm{~N}$ & $\mathrm{NH}$ & 1 & $\mathrm{C}_{6} \mathrm{H}_{5}$ & $\mathrm{NH}$ & 1 & $\mathrm{C}_{6} \mathrm{H}_{5}$ & 0 & 8 \\
\hline $7 c$ & $\mathrm{C}$ & $\mathrm{NH}$ & 4 & $\mathrm{C}_{6} \mathrm{H}_{5}$ & $\mathrm{NH}$ & 4 & $\mathrm{C}_{6} \mathrm{H}_{5}$ & 0 & $>10$ \\
\hline $7 d$ & $\mathrm{~N}$ & $\mathrm{NH}$ & 4 & $\mathrm{C}_{6} \mathrm{H}_{5}$ & $\mathrm{NH}$ & 4 & $\mathrm{C}_{6} \mathrm{H}_{5}$ & 0 & $>10$ \\
\hline $7 e$ & $\mathrm{C}$ & $\mathrm{NH}$ & 1 & $4-\mathrm{SCH}_{3}-\mathrm{C}_{6} \mathrm{H}_{4}$ & $\mathrm{NH}$ & 1 & $4-\mathrm{SCH}_{3}-\mathrm{C}_{6} \mathrm{H}_{4}$ & 0 & 1.7 \\
\hline $7 f$ & $\mathrm{~N}$ & $\mathrm{NH}$ & 1 & $4-\mathrm{SCH}_{3}-\mathrm{C}_{6} \mathrm{H}_{4}$ & $\mathrm{NH}$ & 1 & $4-\mathrm{SCH}_{3}-\mathrm{C}_{6} \mathrm{H}_{4}$ & 0 & 1.5 \\
\hline $7 g$ & $\mathrm{C}$ & $\mathrm{NH}$ & 0 & $4-\mathrm{SeCN}-\mathrm{C}_{6} \mathrm{H}_{4}$ & $\mathrm{NH}$ & 0 & $4-\mathrm{SeCN}-\mathrm{C}_{6} \mathrm{H}_{4}$ & 0 & 9.4 \\
\hline $7 \mathrm{~h}$ & $\mathrm{~N}$ & $\mathrm{NH}$ & 1 & $4-\mathrm{SeCH}_{3}-\mathrm{C}_{6} \mathrm{H}_{4}$ & $\mathrm{NH}$ & 1 & $4-\mathrm{SeCH}_{3}-\mathrm{C}_{6} \mathrm{H}_{4}$ & 0 & 3.2 \\
\hline $8 \mathbf{8}$ & $\mathrm{C}$ & $\mathrm{NH}$ & 1 & $\mathrm{C}_{6} \mathrm{H}_{5}$ & $\mathrm{NH}$ & 1 & $\mathrm{C}_{6} \mathrm{H}_{5}$ & 1 & 8.2 \\
\hline $8 b$ & $\mathrm{~N}$ & $\mathrm{NH}$ & 1 & $\mathrm{C}_{6} \mathrm{H}_{5}$ & $\mathrm{NH}$ & 1 & $\mathrm{C}_{6} \mathrm{H}_{5}$ & 1.5 & 7.9 \\
\hline $8 c$ & $\mathrm{C}$ & $\mathrm{NH}$ & 4 & $\mathrm{C}_{6} \mathrm{H}_{5}$ & $\mathrm{NH}$ & 4 & $\mathrm{C}_{6} \mathrm{H}_{5}$ & 1 & 6.3 \\
\hline $8 d$ & $\mathrm{~N}$ & $\mathrm{NH}$ & 4 & $\mathrm{C}_{6} \mathrm{H}_{5}$ & $\mathrm{NH}$ & 4 & $\mathrm{C}_{6} \mathrm{H}_{5}$ & 0.75 & $>10$ \\
\hline $8 e$ & $\mathrm{C}$ & $\mathrm{NH}$ & 1 & $4-\mathrm{SCH}_{3}-\mathrm{C}_{6} \mathrm{H}_{4}$ & $\mathrm{NH}$ & 1 & $4-\mathrm{SCH}_{3}-\mathrm{C}_{6} \mathrm{H}_{4}$ & 1.85 & 1.6 \\
\hline $8 f$ & $\mathrm{~N}$ & $\mathrm{NH}$ & 1 & $4-\mathrm{SCH}_{3}-\mathrm{C}_{6} \mathrm{H}_{4}$ & $\mathrm{NH}$ & 1 & $4-\mathrm{SCH}_{3}-\mathrm{C}_{6} \mathrm{H}_{4}$ & 0.4 & 1.8 \\
\hline Topotecan & & & & & & & & & 4.0 \\
\hline $\mathbf{M S A}^{\mathbf{b}}$ & & & & & & & & & 8.4 \\
\hline
\end{tabular}

${ }^{\mathbf{a}}$ PC-3 cell line; ${ }^{\mathbf{b}}$ Methylseleninic acid.

b) Antioxidant activity

Since antioxidants are gaining attention as a potential means of treating a large number of lifestyle diseases like cancer, it is of immense significance to establish some new antioxidants via a convenient synthetic methodology. In addition, selenium derivatives are being studied due to their antioxidant properties. ${ }^{50,51}$ The DPPH radical has been widely used to test the ability of compounds to behave as free radical scavengers or hydrogen donors. Briefly, the assay measures the decrease in absorbance of the DPPH radicals at a characteristic wavelength after $60 \mathrm{~min}$ incubation of the DPPH radical with different concentrations (from $62.5 \mu \mathrm{M}$ to $312.5 \mu \mathrm{M}$ ) of the antioxidant compound according to the method of Koparir et al. ${ }^{52}$ The absorbance of the reaction mixture was recorded at $517 \mathrm{~nm}$ using a UV visible spectrophotometer (Jasco V-630). Ascorbic acid was used as standard. Results are expressed as the percentage of the DPPH free radical scavenging at five concentrations, as shown in Table 2. Each value is expressed as the average of three experiments per concentration \pm SD. Although all the compounds were tested, Table 2 only shows the data obtained for the derivatives that exhibited some activity. 6d showed the best 
DPPH radical scavenging activity in comparison with ascorbic acid used as reference, followed by compounds $7 \mathbf{f}, \mathbf{5 c}, \mathbf{6 c}, \mathbf{7 g}, 5 \mathbf{a}$ and $8 \mathrm{e}$. In general, analogues with quinazoline moiety presented better DPPH radical scavenging activity at the concentrations tested than compounds with pyridopyrimidine moiety with the exception of $\mathbf{6} \mathbf{d}$ and $\mathbf{7 f}$.

Table 2. Percentages of free radical scavenging activity (DPPH radical) obtained for the compounds at different concentrations

\begin{tabular}{cccccc}
\hline Compound & $62.5 \mu \mathrm{M}$ & $125 \mu \mathrm{M}$ & $187.5 \mu \mathrm{M}$ & $250 \mu \mathrm{M}$ & $312.5 \mu \mathrm{M}$ \\
\hline $\mathbf{5 a}$ & $25.9 \pm 0.1$ & $32.9 \pm 0.2$ & $36.7 \pm 0.1$ & $48.3 \pm 0.1$ & $55.6 \pm 0.1$ \\
$\mathbf{5 b}$ & $3.4 \pm 0.1$ & $11.9 \pm 0.1$ & $12.2 \pm 0.1$ & $15.3 \pm 0.2$ & $16.3 \pm 0.1$ \\
$\mathbf{5 c}$ & $37.9 \pm 0.2$ & $59.5 \pm 0.1$ & $68.1 \pm 0.1$ & $70.5 \pm 0.1$ & $71.9 \pm 0.1$ \\
$\mathbf{6 c}$ & $27.1 \pm 0.2$ & $38.2 \pm 0.2$ & $45.6 \pm 0.1$ & $51.1 \pm 0.1$ & $56.7 \pm 0.2$ \\
$\mathbf{6 d}$ & $52.9 \pm 0.1$ & $63.6 \pm 0.4$ & $72.4 \pm 0.2$ & $87.6 \pm 0.4$ & $95.7 \pm 0.5$ \\
$\mathbf{7 f}$ & $32.3 \pm 0.1$ & $62.3 \pm 0.1$ & $76.8 \pm 0.2$ & $77.2 \pm 0.2$ & $82.1 \pm 0.1$ \\
$\mathbf{7 g}$ & $39.2 \pm 0.1$ & $49.8 \pm 0.1$ & $56.9 \pm 0.2$ & $63.6 \pm 0.1$ & $68.4 \pm 0.1$ \\
$\mathbf{7 h}$ & $9.2 \pm 0.1$ & $14.2 \pm 0.2$ & $17.2 \pm 0.1$ & $20.1 \pm 0.1$ & $22.4 \pm 0.1$ \\
$\mathbf{8 e}$ & $16.3 \pm 0.1$ & $31.4 \pm 0.1$ & $41.1 \pm 0.1$ & $43.6 \pm 0.3$ & $50.6 \pm 0.1$ \\
$\mathbf{8 f}$ & $16.1 \pm 0.1$ & $22.9 \pm 0.2$ & $24.6 \pm 0.1$ & $27.6 \pm 0.3$ & $28.1 \pm 0.1$ \\
Ascorbic acid & $52.7 \pm 0.4$ & $63.4 \pm 0.1$ & $69.2 \pm 0.2$ & $70.4 \pm 0.1$ & $72.8 \pm 0.1$ \\
\hline
\end{tabular}

aAscorbic acid (reference antioxidant compounds) was used as a standard. The scavenging capacities were represented as percentage inhibition and values were the means of three replicates (mean $\pm \mathrm{SD}, \mathrm{n}=3$ ).

c) Mechanism Studies

Since some compounds had strong inhibitory effects on the growth of the cancer cell line tested, and/or antioxidant activity, we decided to study the effect of three compounds (5d, $6 \mathbf{d}$ and $\mathbf{7 f}$ ) in greater detail in order to know their mode of action. 6d, formulated as hydroselenite salt, because it is active against PC-3 and exhibited a marked antioxidant activity being better than ascorbic acid used as positive control; its analogue $\mathbf{5 d}$ with the same chemical structure in order to explore the importance of the presence of hydroselenite group in the mechanism of action and 7f, 
which was the most active as cytotoxic agent $\left(\mathrm{IC}_{50}=1.5 \mu \mathrm{M}\right)$ and one of the most potent derivative as DPPH radical scavenging.

First, we investigated the effects of these three compounds on caspase activity. We focused on caspase-3, which is activated by a great number of apoptotic signals. This enzyme is the main executor of apoptosis playing a central role in its biological processing. It has been reported that activation of caspase-3 is an essential event for the induction of oligonucleosomal DNA fragmentation. ${ }^{53}$

We analysed the effect of treatment with $\mathbf{5 d}, \mathbf{6 d}$ and $7 \mathbf{f}$ on caspase-3 activation in PC-3 at a concentration of $15 \mu \mathrm{M}$ after 24 and $48 \mathrm{~h}$ of treatment. As shown in Figure 1, the activity of caspase- 3 in cells exposed to compound $\mathbf{6 d}$ increased slightly comparing to control after $24 \mathrm{~h}$, although this effect disappeared after $48 \mathrm{~h}$. However, the analogue without hydroselenite salt (5d) and compound $7 \mathbf{f}$ did not modify the caspase-3 level at the times tested.

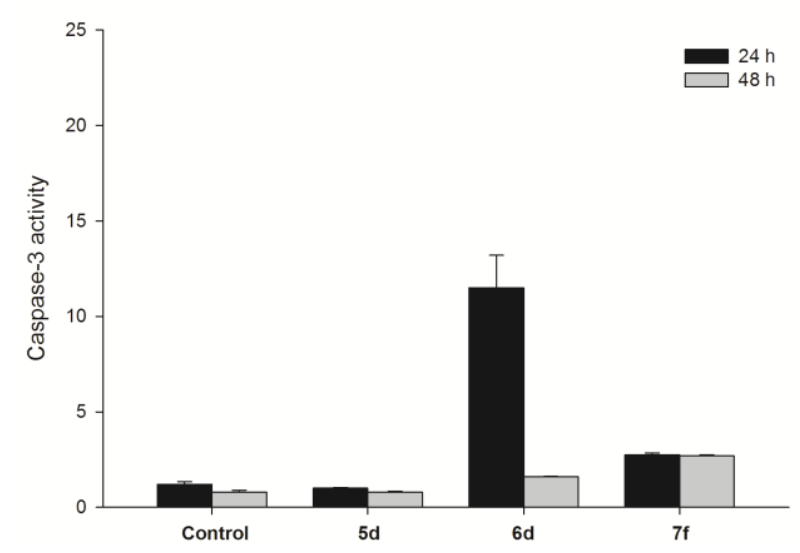

Figure 1. Assessment of caspase-3 activity in PC-3 cell line.

Then, these compounds were selected for further evaluation on their effects of PC-3 cell cycle distribution by flow cytometric analysis using propidium iodide at 24 and $48 \mathrm{~h}$. It is known that cell cycle dysregulation is a hallmark of anticancer drug-induced cell death and many anticancer drugs interact with cells leading to cell growth arrest. ${ }^{54}$ To determine whether the anticancer effects of the compounds were caused by cell cycle modulation, the effects of compounds 5d, 6d and 7f on cell cycle progression were examined in PC-3 cell line at a concentration of $15 \mu \mathrm{M}$. After $24 \mathrm{~h}$ and $48 \mathrm{~h}$ of treatment, compound $\mathbf{5 d}$ did not induce any specific phase arrest of the cell cycle related to control. In contrast, $6 \mathbf{d}$ at $24 \mathrm{~h}$ provoked an increase in phases subG $\mathrm{G}_{0} / \mathrm{G}_{1}$ and $\mathrm{G}_{2} / \mathrm{M}$ with a significant reduction of $\mathrm{G}_{0} / \mathrm{G}_{1}$. On the other hand, 7f induced a slightly decrease in the $\mathrm{G}_{0} / \mathrm{G}_{1}$ population with a weak increase in other phases ( $\mathrm{S}$ and $\mathrm{G}_{2} / \mathrm{M}$ ). In all the cases these effects disappear at $48 \mathrm{~h}$. Cell accumulation in $\mathrm{G}_{2} / \mathrm{M}$ phase, accompanied by a diminution of cell proportion in $\mathrm{G}_{0} / \mathrm{G}_{1}$ phase accompanied by a significant 
increase in subGo/G $\mathrm{G}_{1}$ phase (which is representative of cell with fragmented DNA) could suggest a mitotic arrest prior to metaphase. Figure 2 summarizes the results of cell cycle distribution.

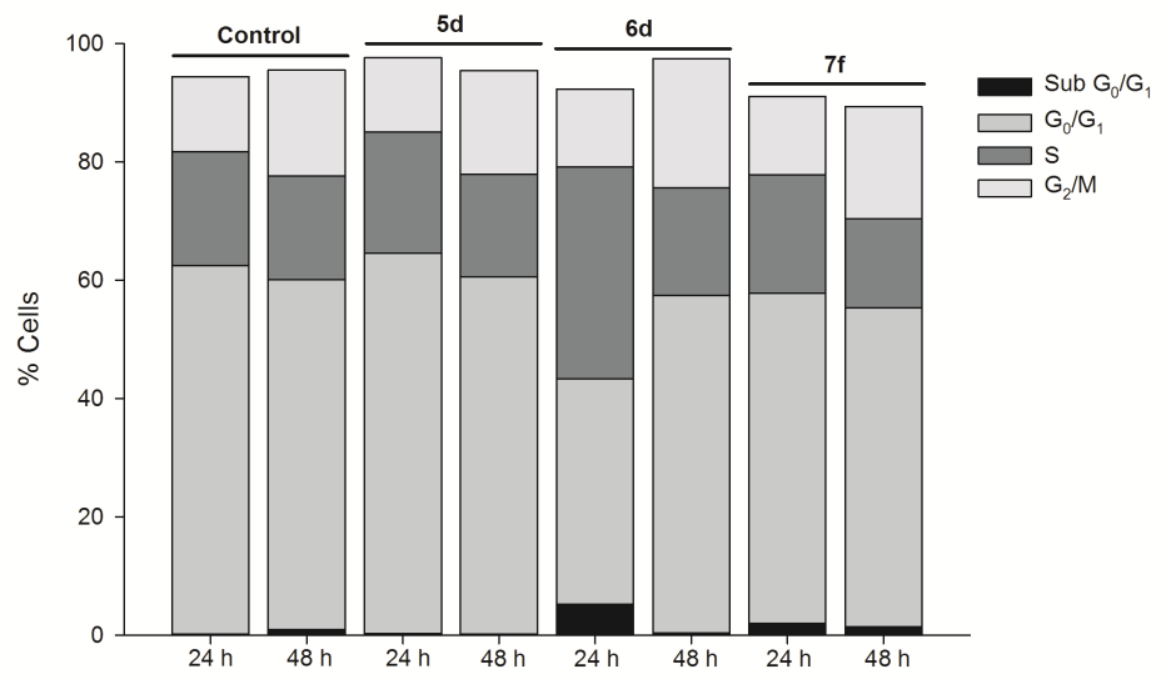

Figure 2. Effects of $\mathbf{5 d}, \mathbf{6 d}$ and $\mathbf{7 f}$ on cell cycle distribution in PC-3 cells.

d) Theoretical evaluation of ADME properties

To better understand the properties of the compounds, the theoretical ADME properties such as molecular weight, $\log P$, TPSA (a predictive indicator of membrane penetration), volume and number of hydrogen donors and acceptors were calculated (Table 3) using the Molinspiration property calculation program. ${ }^{55}$

From the obtained results, it is important to point out that the three selected compounds (5d, 6d and 7f) possess acceptable log $\mathrm{P}$ values, which mean that these derivatives could be able to cross membranes. Furthermore, values obtained from TPSA are also found to be positive. It can also be observed no violations of Lipinski's rule (Table 3). It is remarkable that this freely accessible program do not allow to include the hydroselenite salt formulation in the structure so the values obtained for compound $\mathbf{6 d}$ were determined by protonation of the amine group.

Table 3. Theoretical structural properties of the selected compounds

Comp. $\log P \quad$ MW TPSA n-OH acceptors n-OHNH donors Volume

\begin{tabular}{ccccccc}
\hline $\mathbf{5 d}$ & 4.69 & 324.45 & 50.70 & 4 & 1 & 301.27 \\
$\mathbf{6 d}$ & 1.67 & 453.45 & 55.28 & 4 & 2 & 302.25 \\
$\mathbf{7 f}$ & 4.88 & 433.61 & 62.73 & 5 & 2 & 386.17 \\
\hline
\end{tabular}




\section{Conclusions}

The current study reports the synthesis of twenty-two quinazolines, pyrido[2,3- $d]$ pyrimidines and their hydroselenite salts and the in vitro growth inhibitory activity against tumoral PC-3 cell line as well as their antioxidant activity considered as the interaction with the free radical DPPH. It was observed from the results of biological assays that twelve compounds $(\mathbf{5 d}, \mathbf{6 a}, \mathbf{6 c}, \mathbf{6 d}, \mathbf{7 b}$, 7e, 7f, 7h, 8b, 8c, 8e and 8f) showed potent growth inhibitory activity ( $\mathrm{IC}_{50}<8.0 \mu \mathrm{M}$ ) and were more potent than standard drug methylseleninic acid $\left(\mathrm{IC}_{50}=8.4 \mu \mathrm{M}\right)$. In addition, seven of them $(6 \mathbf{a}, 6 \mathbf{c}, 7 \mathbf{7}, 7 \mathbf{f}, 7 \mathbf{h}, 8 \mathbf{e}$ and $\mathbf{8 f})$ were more active than topotecan with $\mathrm{IC}_{50}$ below than $4.0 \mu \mathrm{M}$. On the ground of the biological results, some structural features were inferred to be beneficial to the antitumor activity of such compounds. Cytotoxic data confirmed that molecular symmetry is a valid approach to obtain potent antitumor agents. In general, the hydroselenite salt formulation had a beneficial effect on the cytotoxic activity for 2 and 2 and 4-phenylalkylamino derivatives when the aryl ring was not functionalizated. Meanwhile, the modification of the length in the alkyl chain substituent was not accompanied by alteration of antitumor activity. The effect of the replacement of quinazoline by pyridopyrimidine scaffold was dependent of the nature of the substituents.

Two compounds $\mathbf{6 d}$ and $7 \mathbf{f}$ exhibited strong cytotoxic and antioxidant activities in comparison to the positive controls and they were selected for further studies related to caspase- 3 activity and cell cycle regulation. Compound $\mathbf{6} \mathbf{d}$ provoked caspase-3 activation and cell cycle arrest in a time-dependent manner being these effects less marked for 7f. In addition, the described compounds seem to present desirable ADME properties that could be an important information about the promising potential of these derivatives.

These compounds may become a promising class of cytotoxic and antioxidant agents and the results provide an insight for future direction in the development of new molecules.

\section{Experimental Section}

\section{Chemistry}

General. Melting points were determined with a Mettler FP82+FP80 apparatus (Greifense, Switzerland) and have not been corrected. The ${ }^{1} \mathrm{H}$ NMR spectra were recorded on a Bruker 400 Ultrashield $^{\mathrm{TM}}$ spectrometer (Rheinstetten, Germany) using TMS as the internal standard. The IR spectra were obtained on a Thermo Nicolet FT-IR Nexus spectrophotometer with KBr pellets. Elemental microanalyses were carried out on vacuum-dried samples using a LECO CHN-900 Elemental Analyzer. Silica gel 60 (0.040-0.063 mm) 1.09385.2500 (Merck KGaA, 64271 Darmstadt, Germany) was used for Column Chromatography and Alugram ${ }^{\circledR}$ SIL G/UV 254 (Layer: $0.2 \mathrm{~mm}$ ) (Macherey-Nagel GmbH \& Co. KG. Postfach 101352, D-52313 Düren,

Germany) was used for Thin Layer Chromatography. Chemicals were purchased from E. Merck (Darmstadt, Germany), Scharlau (F.E.R.O.S.A., Barcelona, Spain), Panreac Química S.A. 
(Montcada i Reixac, Barcelona, Spain), Sigma-Aldrich Química, S.A. (Alcobendas, Madrid, Spain), Acros Organics (Janssen Pharmaceuticalaan 3a, 2440 Geel, Belgium), Shanghai Richem International Co., Ltd and Lancaster (Bischheim-Strasbourg, France).

\section{General procedure for compounds 5a-5d}

A solution of the corresponding 2-methylthio-4-chloroquinazoline (3) or the suitable pyrido[2,3d]pyrimidine (4) $(4.0 \mathrm{mmol})$ in ethanol $(25 \mathrm{~mL})$ was cooled to $4{ }^{\circ} \mathrm{C}$ and the proper amine $(4.4$ mmol) was added. The mixture was stirred at room temperature for 5-6 $\mathrm{h}$ and after heating at 75 ${ }^{\circ} \mathrm{C}$ during $15 \mathrm{~h}$, it was concentrated. The residue was treated with water and the precipitate was collected by filtration, washed with $\mathrm{Et}_{2} \mathrm{O}(3 \times 15 \mathrm{~mL})$ and recrystallized from the appropriate solvent.

Compounds 4-benzylamino-2-methylthioquinazoline (5a), 4-benzylamino-2-methylthiopyrido [2,3-d]pyrimidine (5b) and 2-methylthio-4-(4-phenylbutyl)aminoquinazoline (5c) were synthesized according to the procedure previously reported by us and the spectroscopical data obtained were congruent. $^{31}$

4-(4-Phenylbutylamino)-2-methylthiopyrido[2,3-d]pyrimidine $\quad(5 d)$ From 4-chloro-2methylthiopyrido[2,3- $d]$ pyrimidine and 4-phenylbutylamine. Recrystallized from ethanol. Yield 43\%, mp 175-176 ${ }^{\circ} \mathrm{C}$; IR ( $\left.v_{\max }, \mathrm{cm}^{-1}\right): 3247$ (w, N-H). ${ }^{1} \mathrm{H}$ NMR (400 MHz, DMSO- $\left.d_{6}\right): \delta_{\mathrm{H}} 1.64$ (s, 4H, $\left.\mathrm{CH}_{2}-\mathrm{CH}_{2}-\mathrm{CH}_{2}-\mathrm{CH}_{2}\right), 2.49$ (s, 3H, SCH 3$), 2.62$ (s, 2H, CH $\left.2-\mathrm{Ph}\right), 3.53$ (s, 2H, NH-CH$)$, 7.14-7.25 (m. 5H, $\mathrm{H}_{2}{ }^{\prime}, \mathrm{H}_{3}{ }^{\prime}, \mathrm{H}_{4}{ }^{\prime}, \mathrm{H}_{5}, \mathrm{H}_{6}$ ), 7.38 (s, 1H, $\mathrm{H}_{6}$ ), 8.59-8.61 (bs, 2H, $\left.\mathrm{H}_{5}, \mathrm{NH}\right), 8.84$ (s, $\left.1 \mathrm{H}, \mathrm{H}_{7}\right)$. MS (m/z, \%) $324\left(\mathrm{M}^{+}, 97\right), 219$ (100). Anal. Calcd for $\mathrm{C}_{18} \mathrm{H}_{20} \mathrm{~N}_{4} \mathrm{~S} \cdot 0.3 \mathrm{H}_{2} \mathrm{O}: \mathrm{C}, 65.57 ; \mathrm{H}$, 6.16; N, 17.00. Found: C, 65.65; H, 6.17; N, 16.67.

General procedure for compounds 6a-6d. The corresponding derivatives $5 \mathbf{a}-5 \mathbf{d}$ (1 mmol) were dissolved in ethanol:water $(1: 1,50 \mathrm{~mL})$ and selenium dioxide $(1.5 \mathrm{mmol})$ was added carefully. The resulting mixture was heated and stirred during $12 \mathrm{~h}$ and the solvent was removed under reduced pressure. The residue was washed with ethyl ether $(4 \times 25 \mathrm{~mL})$, dried and recrystallized from ethanol.

4-Benzylamino-2-methylthioquinazoline-1.97 hydroselenite (6a). From 4-benzylamino-2methylthioquinazoline and selenium dioxide. Yield $50 \%$, mp 106-107 ${ }^{\circ} \mathrm{C}$; IR $\left(v_{\max }, \mathrm{cm}^{-1}\right): 3228$ $(\mathrm{m}, \mathrm{N}-\mathrm{H}) .{ }^{1} \mathrm{H}$ NMR $\left(400 \mathrm{MHz}, \mathrm{DMSO}-d_{6}\right): \delta_{\mathrm{H}} 2.45$ (s, 3H, SCH 3$), 4.75$ (d, 2H, NH-CH $\mathrm{SH}_{\mathrm{CH} 2-\mathrm{NH}}$ $=5.8 \mathrm{~Hz}), 5.55\left(\mathrm{bs}, 1 \mathrm{H}, \mathrm{NH}-\mathrm{H}_{2} \mathrm{SeO}_{3}\right), 7.24\left(\mathrm{dd}, 1 \mathrm{H}, \mathrm{H}_{7}, J_{7-8}=8.3 \mathrm{~Hz}, J_{7-6}=7.1 \mathrm{~Hz}\right)$, 7.36-7.41 $\left(\mathrm{m}, 6 \mathrm{H}, \mathrm{H}_{8}, \mathrm{H}_{2}, \mathrm{H}_{3}, \mathrm{H}_{4}, \mathrm{H}_{5}, \mathrm{H}_{6}\right.$ ), 7.54 (d, 1H, $\left.\mathrm{H}_{6}\right), 8.22\left(\mathrm{dd}, 1 \mathrm{H}, \mathrm{H}_{5}, J_{5-7}=1.8 \mathrm{~Hz}\right), 8.93$ (t, $1 \mathrm{H}, \mathrm{NH})$. MS (m/z, \%) $281\left(\mathrm{M}^{+}, 100\right)$. Anal. Calcd for $\mathrm{C}_{16} \mathrm{H}_{15} \mathrm{~N}_{3} \mathrm{~S} .1 .97 \mathrm{H}_{2} \mathrm{SeO}_{3}$ : C, 35.97; H, $3.60 ;$ N, 7.70. Found: C, 63.52; H, 5.15; N, 19.68 .

4-Benzylamino-2-methylthiopyrido[2,3-d]pyrimidine-0.45 hydroselenite (6b). From 4benzylamino-2-methylthiopyrido[2,3- $d$ ]pyrimidine and selenium dioxide. Yield $94 \%$, mp 197$198^{\circ} \mathrm{C}$; IR ( $\left.v_{\max }, \mathrm{cm}-1\right): 3254$ (m, N-H). ${ }^{1} \mathrm{H}$ NMR (400 MHz, DMSO-d $)$ ): $\delta_{\mathrm{H}} 2.47$ (s, 3H, $\mathrm{SCH}_{3}$ ), 3.51 (bs, $\left.1 \mathrm{H}, \mathrm{NH}-\mathrm{H}_{2} \mathrm{SeO}_{3}\right), 4.75$ (d, 2H, NH-CH$\left.{ }_{2}, J_{\mathrm{CH} 2-\mathrm{NH}}=4.8 \mathrm{~Hz}\right), 7.34-7.38\left(\mathrm{~m}, 5 \mathrm{H}, \mathrm{H}_{2}\right.$, , $\mathrm{H}_{3}$ ', $\left.\mathrm{H}_{4}, \mathrm{H}_{5}, \mathrm{H}_{6}\right), 8.66\left(\mathrm{~d}, 1 \mathrm{H}, \mathrm{H}_{6}, J_{6-5}=8.4 \mathrm{~Hz}, J_{6-7}=4.1 \mathrm{~Hz}\right), 8.86\left(\mathrm{dd}, 1 \mathrm{H}, \mathrm{H}_{5}, J_{5-7}=2.1 \mathrm{~Hz}\right)$, 9.20 (dd, $\left.1 \mathrm{H}, \mathrm{H}_{7}\right)$. MS (m/z, \%) 156 (100). Anal. Calcd for $\mathrm{C}_{15} \mathrm{H}_{14} \mathrm{~N}_{4} \mathrm{~S} \cdot 0.45 \mathrm{H}_{2} \mathrm{SeO}_{3}: \mathrm{C}, 52.93 ; \mathrm{H}$, 
4.38; N, 16.47. Found: C, 52.84; H, 4.15; N, 16.39 .

4-(4-Phenylbutylamino)-2-methylthioquinazoline•1.25 hydroselenite (6c). From 4-(4phenylbutylamino)-2-methylthioquinazoline and selenium dioxide. Yield $48 \%, \mathrm{mp} 166-167{ }^{\circ} \mathrm{C}$; IR $\left(v_{\max }, \mathrm{cm}^{-1}\right): 3207(\mathrm{~m}, \mathrm{~N}-\mathrm{H}) .{ }^{1} \mathrm{H}$ NMR $\left(400 \mathrm{MHz}, \mathrm{DMSO}-d_{6}\right): \delta_{\mathrm{H}} 1.68-1.69\left(\mathrm{~m}, 4 \mathrm{H}, \mathrm{NH}-\mathrm{CH}_{2}-\right.$ $\left.\left(\underline{\mathrm{CH}}_{2}\right)_{2}-\mathrm{CH}_{2}-\mathrm{Ph}\right), 2.57$ (s, 3H, SCH 3$), 2.63-2.65$ (m, 2H, NH- $\left.\left(\mathrm{CH}_{2}\right)_{3}-\mathrm{CH}_{2}-\mathrm{Ph}\right), 3.63-3.66$ (m, 2H, NH-CH ${ }_{2}$ ), 5.55 (bs, $1 \mathrm{H}, \mathrm{NH}-\mathrm{H}_{2} \mathrm{SeO}_{3}$ ), 7.20-7.22 (m, 5H, $\left.\mathrm{H}_{2}, \mathrm{H}_{3}, \mathrm{H}_{4}, \mathrm{H}_{5}, \mathrm{H}_{6}{ }^{\prime}\right), 7.49$ (t, 1H, $\left.\mathrm{H}_{7}, J_{7-8}=8.3 \mathrm{~Hz}, J_{7-6}=7.8 \mathrm{~Hz}\right), 7.60\left(\mathrm{~d}, 1 \mathrm{H}, \mathrm{H}_{8}\right), 7.80\left(\mathrm{t}, 1 \mathrm{H}, \mathrm{H}_{6}, J_{6-5}=7.8 \mathrm{~Hz}\right), 8.35\left(\mathrm{~d}, 1 \mathrm{H}, \mathrm{H}_{5}\right)$, 9.45 (bs, $1 \mathrm{H}, \mathrm{NH})$. MS (m/z, \%) $323\left(\mathrm{M}^{+}, 100\right)$. Anal. Calcd for $\mathrm{C}_{19} \mathrm{H}_{21} \mathrm{~N}_{3} \mathrm{~S} \cdot 1.25 \mathrm{H}_{2} \mathrm{SeO}_{3}$ : C, 47.01; H, 4.61; N, 8.67. Found: C, 46.69; H, 5.01; N, 8.32.

4-(4-Phenylbutylamino)-2-methylthiopyrido[2,3-d]pyrimidine hydroselenite (6d). From 4(4-phenylbutylamino)-2-methylthiopyrido[2,3-d]pyrimidine and selenium dioxide. Yield 86\%, mp 165-166 ${ }^{\circ} \mathrm{C}$; IR $\left(v_{\max }, \mathrm{cm}^{-1}\right): 3240(\mathrm{w}, \mathrm{N}-\mathrm{H}) .{ }^{1} \mathrm{H}$ NMR (400 MHz, DMSO- $\left.d_{6}\right): \delta_{\mathrm{H}} 1.69$ (s, 4H, $\left.\mathrm{CH}_{2}-\mathrm{CH}_{2}-\mathrm{CH}_{2}-\mathrm{CH}_{2}\right), 2.56$ (s, 3H, $\left.\mathrm{SCH}_{3}\right), 2.63$ (s, 2H, $\left.\mathrm{CH}_{2}-\mathrm{Ph}\right), 3.66$ (s, 2H, NH-CH ), 4.35 (bs, 1H, NH-H $\mathrm{SeO}_{3}$ ), 7.16-7.26 (m, 5H, $\mathrm{H}_{2}, \mathrm{H}_{3}, \mathrm{H}_{4}, \mathrm{H}_{5}, \mathrm{H}_{6}$ ), 7.64 (s, 1H, $\left.\mathrm{H}_{6}\right), 8.82$ (s, 1H, H5), $8.92\left(\mathrm{~s}, 1 \mathrm{H}, \mathrm{H}_{7}\right), 9.73(\mathrm{~s}, 1 \mathrm{H}, \mathrm{NH}) . \mathrm{MS}(\mathrm{m} / \mathrm{z}, \%) 324\left(\mathrm{M}^{+}, 72\right), 219$ (100). Anal. Calcd for $\mathrm{C}_{18} \mathrm{H}_{20} \mathrm{~N}_{4} \mathrm{~S} \cdot \mathrm{H}_{2} \mathrm{SeO}_{3}$ : C, 47.68; H, 4.86; N, 12.36. Found: C, 48.00; H, 4.83; N, 12.43.

\section{General procedure for compounds $7 \mathrm{a}-7 \mathrm{~h}$}

To a solution of the corresponding 2,4-dichloroquinazoline or 2,4-dichloropyrido[2,3$d$ ]pyrimidine $(5.0 \mathrm{mmol})$, and equimolecular amounts of triethylamine in ethanol $(25 \mathrm{~mL})$, the corresponding amine $(11 \mathrm{mmol})$ was added. The mixture was stirred for $12 \mathrm{~h}$ at $70{ }^{\circ} \mathrm{C}$. The solvent was removed under vacuum. Then, the residue was treated with water $(75 \mathrm{~mL})$ and the corresponding solid was purified by recrystallization from ethanol.

$N, N^{\prime}$-Dibenzylaminoquinazolin-2,4-diamine (7a), $N, N^{\prime}$-dibenzylaminopyrido[2,3-d]pyrimidin2,4-diamine (7b) $\quad N, N^{\prime}$-bis(4-phenylbutyl)quinazolin-2,4-diamine (7c) and $N, N^{\prime}$-bis(4phenylbutyl)pyrido[2,3-d]pyrimidin-2,4-diamine (7d) were synthesized according to the procedure previously reported by us. ${ }^{30}$

$\boldsymbol{N}, \boldsymbol{N}^{\prime}$-Bis(4-methylthiobenzyl)quinazoline-2,4-diamine hydrochloride (7e). From 2,4dichloroquinazoline and 4-methylthiobenzylamine. Yield 41\%, mp 165-166 ${ }^{\circ} \mathrm{C}$; IR $\left(v_{\max }, \mathrm{cm}^{-1}\right)$ : 3292 (w, N-H). ${ }^{1} \mathrm{H}$ NMR (400 MHz, DMSO- $\left.d_{6}\right): \delta_{\mathrm{H}} 2.43$ (s, 6H, $\left.2 \mathrm{SCH}_{3}\right), 4.52$ and $4.67(\mathrm{~d}+\mathrm{d}$, $\left.4 \mathrm{H}, 2\left(\mathrm{CH}_{2}\right) J_{\mathrm{CH} 2-\mathrm{NH}}=5.8 \mathrm{~Hz}\right), 7.15\left(\mathrm{bs}, 8 \mathrm{H}, 2 \mathrm{H}_{2}, \mathrm{H}_{3}, 2 \mathrm{H}_{5}, 2 \mathrm{H}_{6}\right.$ ), 7.24 (bs, 1H, $\left.\mathrm{H}_{6}\right), 7.33$ (bs, $\left.1 \mathrm{H}, \mathrm{H}_{7}\right), 7.59$ (bs, $\left.1 \mathrm{H}, \mathrm{H}_{5}\right), 8.13$ (bs, $\left.1 \mathrm{H}, \mathrm{H}_{8}\right), 9.72$ (bs, 2H, 2NH). MS (m/z, \%) $432\left(\mathrm{M}^{+}, 33\right)$, 137 (100). Anal. Calcd for $\mathrm{C}_{24} \mathrm{H}_{24} \mathrm{~N}_{4} \mathrm{~S}_{2} \cdot \mathrm{HCl}$ : C, 61.47; H, 5.34; N, 11.95. Found: C, 61.65; H, $5.70 ; \mathrm{N}, 11.84$.

$N, N$ '-Bis(4-methylthiobenzyl)pyrido[2,3-d]pyrimidin-2,4-diamine 0.9 hydrochloride (7f). From 2,4-dichloropyrido[2,3-d]pyrimidine and 4-methylthiobenzylamine. Yield 42\%, mp 218$220{ }^{\circ} \mathrm{C}$; IR ( $\left.v_{\max }, \mathrm{cm}^{-1}\right): 3268(\mathrm{w}, \mathrm{N}-\mathrm{H}) .{ }^{1} \mathrm{H}$ NMR (400 MHz, DMSO-d $): \delta_{\mathrm{H}} 2.44$ (s, 6H, 2

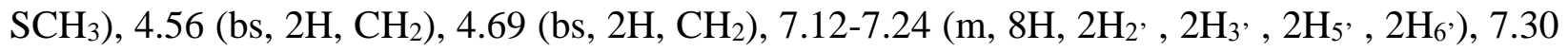
(bs, 1H, $\mathrm{H}_{6}$ ), 8.25 (bs, 1H, NH), 8.63 (bs, 1H, H5), 8.71 (bs, 1H, $\mathrm{H}_{7}$ ), 9.80 (bs, 1H, NH). MS 
$(\mathrm{m} / \mathrm{z}, \%) 433\left(\mathrm{M}^{+}, 58\right), 105$ (100). Anal. Calcd for $\mathrm{C}_{23} \mathrm{H}_{23} \mathrm{~N}_{5} \mathrm{~S}_{2} \cdot 0.9 \mathrm{HCl}: \mathrm{C}, 59.25 ; \mathrm{H}, 5.13 ; \mathrm{N}$, 15.03. Found: C, 59.56; H, 5.08; N, 15.05.

$N, N^{\prime}$-Bis(4-selenocyanatephenyl)quinazoline-2,4-diamine 0.8 hydrochloride (7g). From 2,4dichloroquinazoline and 4-aminophenylselenocyanate. 4-aminophenylselenocyanate was prepared according to the method reported by Kachanov et al. ${ }^{56}$ Yield 45\%, mp 208-209 ${ }^{\circ} \mathrm{C}$; IR $\left(v_{\max }, \mathrm{cm}^{-1}\right): 3190(\mathrm{w}, \mathrm{N}-\mathrm{H}) .{ }^{1} \mathrm{H}$ NMR (400 MHz, DMSO- $\left.d_{6}\right): \delta_{\mathrm{H}} 7.56-7.59\left(\mathrm{~m}, 2 \mathrm{H}, \mathrm{H}_{6}, \mathrm{H}_{7}\right)$,

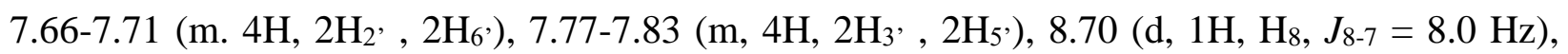
10.71 (bs, 1H, NH), 11.25 (bs, 1H, NH). MS (m/z, \%) 57 (100). Anal. Calcd for $\mathrm{C}_{22} \mathrm{H}_{14} \mathrm{~N}_{6} \mathrm{Se}_{2} \cdot 0.8 \mathrm{HCl}: \mathrm{C}, 48.07$; H, 2.69; N, 15.29. Found: C, 48.35; H, 2.99; N, 15.18.

$N, N$ '-Bis(4-methylselenobenzyl)pyrido[2,3- $d]$ pyrimidin-2,4-diamine 0.5 hydrochloride (7h). From 2,4-dichloropyrido[2,3- $d$ ]pyrimidine and 4-methylselenobencylamine. 4methylselenobenzylamine was prepared according to the procedure previously reported by us. ${ }^{31}$ Yield 38\%, mp 137-139 ${ }^{\circ} \mathrm{C}$; IR $\left(v_{\max }, \mathrm{cm}^{-1}\right): 1611(\mathrm{~m}, \mathrm{C}=\mathrm{N}) .{ }^{1} \mathrm{H}$ NMR (400 MHz, DMSO- $\left.d_{6}\right): \delta_{\mathrm{H}}$ $2.32\left(\mathrm{~s}, 6 \mathrm{H}, 2 \mathrm{SeCH}_{3}\right), 4.78\left(\mathrm{~d}, 4 \mathrm{H}, 2 \mathrm{CH}_{2}, J_{\mathrm{CH} 2-\mathrm{NH}}=5.6 \mathrm{~Hz}\right), 7.21-7.37\left(\mathrm{~m}, 8 \mathrm{H}, 2 \mathrm{H}_{2}\right.$, , 2H $\mathrm{H}_{3}, 2 \mathrm{H}_{5}$, , 2 $\mathrm{H}_{6}$ ) $, 7.56\left(\mathrm{dd}, 1 \mathrm{H}, \mathrm{H}_{6}, J_{6-7}=8.0 \mathrm{~Hz}, J_{6-5}=4.5 \mathrm{~Hz}\right), 8.89\left(\mathrm{~d}, 1 \mathrm{H}, \mathrm{H}_{5}\right), 9.03\left(\mathrm{~d}, 1 \mathrm{H}, \mathrm{H}_{7}\right), 11.48$ (bs, 1H, NH), 11.68 (bs, 1H, NH). MS (m/z, \%) 163 (100). Anal. Calcd for $\mathrm{C}_{23} \mathrm{H}_{23} \mathrm{~N}_{5} \mathrm{Se}_{2} \cdot 0.5$ HCl: C, 50.61; H, 4.31; N, 12.84. Found: C, 50.29; H, 4.53; N, 13.12.

\section{General procedure for compounds 8a-8f}

The corresponding derivatives $7 \mathbf{a}-7 \mathbf{f}(1 \mathrm{mmol})$ were dissolved in ethanol:water $(1: 1,50 \mathrm{~mL})$ and selenium dioxide $(1.5 \mathrm{mmol})$ was added. The resulting mixture was heated and stirred during $3 \mathrm{~h}$ and the solvent was removed under reduced pressure. Finally, the residue was washed with $(4 \times$ $25 \mathrm{~mL}$ ), dried and recrystallized from ethanol.

$\boldsymbol{N}, \boldsymbol{N}^{\prime}$-Dibenzylaminoquinazolin-2,4-diamonium hydroselenite (8a). From $N, N^{\prime}$ dibenzylaminoquinazolin-2,4-diamine and selenium dioxide. Yield $65 \%$, mp 190-192 ${ }^{\circ} \mathrm{C}$; IR $\left(v_{\max }, \mathrm{cm}^{-1}\right): 3442(\mathrm{~s}, \mathrm{~N}-\mathrm{H}) .{ }^{1} \mathrm{H}$ NMR $\left(400 \mathrm{MHz}, \mathrm{DMSO}-d_{6}\right): \delta_{\mathrm{H}} 3.92\left(\mathrm{bs}, \mathrm{H}_{2} \mathrm{SeO}_{3}\right), 4.61$ (d, 2H, $\left.-\mathrm{NH}-\underline{\mathrm{CH}}_{2}-\mathrm{Ph}\right), 4.77\left(\mathrm{~d}, 2 \mathrm{H},-\mathrm{NH}-\underline{\mathrm{CH}}_{2}-\mathrm{Ph}\right), 7.21-7.24\left(\mathrm{~m}, 10 \mathrm{H}, 2 \mathrm{H}_{2}, 2 \mathrm{H}_{3}, 2 \mathrm{H}_{4}, 2 \mathrm{H}_{5}, 2 \mathrm{H}_{6}\right.$ ), 7.42 (t, 1H, H6), 7.48 (t, 1H, H7), $7.76\left(\mathrm{~d}, 1 \mathrm{H}, \mathrm{H}_{5}\right), 8.33$ (d, 1H, H8), 8.55 (bs, 1H, NH), 10.23 (bs, 1H, $\left.\mathrm{NH} \cdot \mathrm{H}_{2} \mathrm{SeO}_{3}\right) . \mathrm{MS}(\mathrm{m} / \mathrm{z}, \%) 340\left(\mathrm{M}^{+}, 25\right), 91(100)$. Anal. Calcd for $\mathrm{C}_{22} \mathrm{H}_{20} \mathrm{~N}_{4} \cdot \mathrm{H}_{2} \mathrm{SeO}_{3}: \mathrm{C}, 56.29$; H, 4.69; N, 11.94. Found: C, 56.32; H, 4.85; N, 12.02 .

$N, N$ '-Dibenzylaminopyrido[2,3-d]pyrimidin-2,4-diamonium•1.5 hydroselenite $(8 \mathrm{~b})$. From $N, N^{\prime}$-dibenzylaminopyrido[2,3-d]pyrimidin-2,4-diamine and selenium dioxide. Yield $73 \%, \mathrm{mp}$ 227-229 ${ }^{\circ} \mathrm{C}$; IR $\left(v_{\max }, \mathrm{cm}^{-1}\right): 3345$ (s, N-H). ${ }^{1} \mathrm{H}$ NMR (400 MHz, DMSO-d6): $\delta_{\mathrm{H}} 4.82$ (d, 4H, $2-$

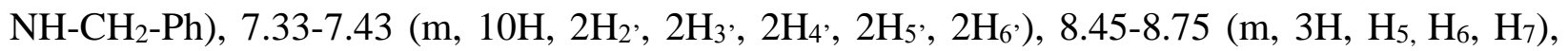
10.53 (bs, $2 \mathrm{H}, 2 \mathrm{NH} \cdot \mathrm{H}_{2} \mathrm{SeO}_{3}$ ). MS (m/z, \%) 91 (100). Anal. Calcd for $\mathrm{C}_{21} \mathrm{H}_{19} \mathrm{~N}_{5} .1 .5 \mathrm{H}_{2} \mathrm{SeO}_{3}$ : C, 47.15; H, 4.11; N, 13.10. Found: C, 47.11; H, 4.35; N, 13.82.

$N, N^{\prime}$-Bis(4-phenylbutyl)quinazolin-2,4-diamonium hydroselenite (8c). From $N, N^{\prime}$-bis(4phenylbutyl)quinazolin-2,4-diamine and selenium dioxide. Yield $47 \%$, mp $148-149{ }^{\circ} \mathrm{C}$; IR $\left(v_{\max }\right.$, $\mathrm{cm}^{-1}$ ): 3325 (s, N-H). ${ }^{1} \mathrm{H}$ NMR (400 MHz, DMSO- $\left.d_{6}\right): \delta_{\mathrm{H}} 1.90$ (d, 4H, $\left.2-\mathrm{NH}-\left(\mathrm{CH}_{2}\right)_{3}-\mathrm{CH}_{2}-\mathrm{Ph}\right)$, 2.56-2.59 (m, 8H, $\left.2-\mathrm{NH}-\mathrm{CH}_{2}-\left(\mathrm{CH}_{2}\right)_{2}-\mathrm{CH}_{2}-\mathrm{Ph}\right), 3.39-3.55$ (m, 4H, $\left.2-\mathrm{NH}-\underline{\mathrm{CH}_{2}}-\left(\mathrm{CH}_{2}\right)_{3}-\mathrm{Ph}\right)$, 
7.18-7.24 (m, 11H, $\mathrm{H}_{6}, 2 \mathrm{H}_{2}, 2 \mathrm{H}_{3}, 2 \mathrm{H}_{4}, 2 \mathrm{H}_{5}, 2 \mathrm{H}_{6}$ ), 7.39 (t, 1H, $\left.\mathrm{H}_{7}\right), 7.76\left(\mathrm{~d}, 1 \mathrm{H}, \mathrm{H}_{5}\right), 8.15$ (bs, $1 \mathrm{H}, \mathrm{NH}), 8.32\left(\mathrm{~d}, 1 \mathrm{H}, \mathrm{H}_{8}\right), 9.70\left(\mathrm{bs}, 1 \mathrm{H}, \mathrm{NH} \cdot \mathrm{H}_{2} \mathrm{SeO}_{3}\right) . \mathrm{MS}(\mathrm{m} / \mathrm{z}, \%)$ 91(100). Anal. Calcd for $\mathrm{C}_{21} \mathrm{H}_{19} \mathrm{~N}_{5} \cdot 1.5 \mathrm{H}_{2} \mathrm{SeO}_{3}$ : C, 47.15; H, 4.11; N, 13.10. Found: C, 47.11; H, 4.35; N, 13.82.

$N, N^{\prime}-B i s(4-p h e n y l b u t y l) p y r i d o[2,3-d]$ pyrimidin-2,4-diamonium•0.75 hydroselenite (8d). From $N, N$ '-bis(4-phenylbutyl)pyrido[2,3-d]pyrimidin-2,4-diamine and selenium dioxide. Yield $32 \%$, mp 127-149 ${ }^{\circ} \mathrm{C}$; IR $\left(v_{\max }, \mathrm{cm}^{-1}\right): 3325$ (s, N-H). ${ }^{1} \mathrm{H}$ NMR (400 MHz, DMSO- $\left.d_{6}\right): \delta_{\mathrm{H}} 1.88$ (d, 4H, $\left.2-\mathrm{NH}-\left(\mathrm{CH}_{2}\right)_{3}-\mathrm{CH}_{2}-\mathrm{Ph}\right), 2.52-2.57$ (m, 8H, $\left.2-\mathrm{NH}-\mathrm{CH}_{2}-\left(\mathrm{CH}_{2}\right)_{2}-\mathrm{CH}_{2}-\mathrm{Ph}\right), 3.35-3.55$ (m, $\left.4 \mathrm{H}, 2-\mathrm{NH}-\mathrm{CH}_{2}-\left(\mathrm{CH}_{2}\right)_{3}-\mathrm{Ph}\right), 7.18-7.24\left(\mathrm{~m}, 11 \mathrm{H}, \mathrm{H}_{6}, 2 \mathrm{H}_{2}, 2 \mathrm{H}_{3}, 2 \mathrm{H}_{4}, 2 \mathrm{H}_{5}, 2 \mathrm{H}_{6}\right.$ ), 7.88 (bs, 1H, $\mathrm{NH}), 8.63\left(\mathrm{~d}, 1 \mathrm{H}, \mathrm{H}_{5}\right), 8.85$ (d, 1H, $\left.\mathrm{H}_{7}\right), 9.70$ (bs, $\left.1 \mathrm{H}, \mathrm{NH} \cdot \mathrm{H}_{2} \mathrm{SeO}_{3}\right)$. MS (m/z, \%) 91 (100). Anal. Calcd for $\mathrm{C}_{21} \mathrm{H}_{19} \mathrm{~N}_{5} \cdot 1.5 \mathrm{H}_{2} \mathrm{SeO}_{3}$ : C, 47.15; H, 4.11; N, 13.10. Found: C, 47.11; H, 4.35; N, 13.82. $N, N$ '-Bis(4-methylthiobenzyl)quinazoline-2,4-diamonium $\cdot 1.85$ hydroselenite $(8 \mathrm{e})$. From $N, N$ '-bis(4-methylthiobenzyl)quinazoline-2,4-diamine and selenium dioxide. Yield 83\%, mp 153-154 ${ }^{\circ} \mathrm{C}$; IR $\left(v_{\max }, \mathrm{cm}^{-1}\right): 3262(\mathrm{w}, \mathrm{N}-\mathrm{H}) .{ }^{1} \mathrm{H}$ NMR (400 MHz, DMSO- $\left.d_{6}\right): \delta_{\mathrm{H}} 2.43$ (s, 6H, 2 $\left.\mathrm{SCH}_{3}\right), 4.49$ and $4.68\left(\mathrm{~s}+\mathrm{s}, 4 \mathrm{H}, 2\left(\mathrm{CH}_{2}\right), 7.15\left(\mathrm{bs}, 8 \mathrm{H}, 2 \mathrm{H}_{2}, 2 \mathrm{H}_{3}, 2 \mathrm{H}_{5}, 2 \mathrm{H}_{6}\right.\right.$ ), 7.37 (bs, $2 \mathrm{H}, \mathrm{H}_{6}$ , $\left.\mathrm{H}_{7}\right), 7.62$ (bs, $\left.1 \mathrm{H}, \mathrm{H}_{5}\right), 8.11$ (bs, 1H, $\left.\mathrm{H}_{8}\right), 9.45$ and 9.63 (bs + bs, 2H, 2NH). MS (m/z, \%) 432 $\left(\mathrm{M}^{+}, 13\right), 137$ (100). Anal. Calcd for $\mathrm{C}_{24} \mathrm{H}_{24} \mathrm{~N}_{4} \mathrm{~S}_{2} .1 .85 \mathrm{H}_{2} \mathrm{SeO}_{3}: \mathrm{C}, 42.90 ; \mathrm{H}, 4.13 ; \mathrm{N}, 8.34$. Found: C, 42.65; H, 3.99; N, 8.32.

$N, N^{\prime}$-Bis(4-methylthiobenzyl)pyrido[2,3-d]pyrimidin-2,4-diamonium $\cdot 0.4 \quad$ hydroselenite (8f). From $N, N^{\prime}$-bis(4-methylthiobencyl)pyrido[2,3-d]pyrimidin-2,4-diamine and selenium dioxide. Yield $79 \%$, mp 152-153 ${ }^{\circ} \mathrm{C}$; IR $\left(v_{\max }, \mathrm{cm}^{-1}\right)$ : 3340 (w, N-H). ${ }^{1} \mathrm{H}$ NMR (400 MHz, DMSO- $\left.d_{6}\right): \delta_{\mathrm{H}} 2.45\left(\mathrm{~s}, 6 \mathrm{H}, 2 \mathrm{SCH}_{3}\right), 3.81\left(\mathrm{bs}, \mathrm{H}_{2} \mathrm{SeO}_{3}\right), 4.63$ and $4.73\left(\mathrm{~d}+\mathrm{d}, 4 \mathrm{H}, 2\left(\mathrm{CH}_{2}\right), J_{\mathrm{CH} 2-}\right.$ $\mathrm{NH}=5.8 \mathrm{~Hz}), 7.12-7.24\left(\mathrm{~m}, 8 \mathrm{H}, 2 \mathrm{H}_{2}, 2 \mathrm{H}_{3}, 2 \mathrm{H}_{5}, 2 \mathrm{H}_{6}\right.$ ), $7.48\left(\mathrm{dd}, 1 \mathrm{H}, \mathrm{H}_{6}, J_{6-7}=7.7 \mathrm{~Hz}, J_{6-5}=\right.$ $4.7 \mathrm{~Hz}), 8.56(\mathrm{~s}, 1 \mathrm{H}, \mathrm{NH}), 8.75\left(\mathrm{~d}, 1 \mathrm{H}, \mathrm{H}_{5}\right), 8.87\left(\mathrm{~d}, 1 \mathrm{H}, \mathrm{H}_{7}\right), 10.59\left(\mathrm{~s}, 1 \mathrm{H}, \mathrm{NH} \cdot \mathrm{H}_{2} \mathrm{SeO}_{3}\right) . \mathrm{MS}$ (m/z, \%) 177 (100). Anal. Calcd for $\mathrm{C}_{23} \mathrm{H}_{23} \mathrm{~N}_{5} \mathrm{~S}_{2} \cdot 0.4 \mathrm{H}_{2} \mathrm{SeO}_{3}$ : C, 56.95; H, 4.91; N, 14.44. Found: C, 57.29; H, 4.96; N, 14.43.

\section{Biological evaluation}

Cytotoxic activity. PC-3 cells were seeded in 96-well plates (Millipore, Eschborn, Germany) at a density of $5 \times 10^{3}$ cells per well. Plates were incubated at $37^{\circ} \mathrm{C}$ under $5 \% \mathrm{CO}_{2}$ overnight prior to the addition of the compounds (diluted in complete medium). After $72 \mathrm{~h}$ of incubation, $10 \mu \mathrm{L}$ of sterile MTT solution ( $5 \mathrm{mg} / \mathrm{mL}$ in PBS) was added to the cells in each well and these plates were stored for an additional $4 \mathrm{~h}$ at $37^{\circ} \mathrm{C}$. The absorbance of formazan crystals were measured at $\lambda=570 \mathrm{~nm}$ on a Polarstar Galaxy plate reader (BMG LabTechnologies $\mathrm{GmbH}$ ). The percentage of viable cells was calculated to obtain $\mathrm{IC}_{50}$-values.

PC-3 are human tumorigenic and metastatic prostate cancer cells and these were obtained from American Type Culture Collection (ATCC), Manassas, USA. The cells were cultured in Dulbecco's RPMI 1640 medium with GlutamaxTM 1 (Invitrogen) supplemented with 10\% fetal bovine serum (Gibco), Fetalclone III, SH30109.03, HYCLONE and 1\% Penicillin-Streotomycin (Invitrogen). 
Antioxidant activity. The antioxidant activity of the compounds was determined by the DPPH method. The free radical-scavenging activity of the title compounds was determined by spectrophotometric measurement of the change in the absorbance of DPPH at $517 \mathrm{~nm}$. Stock solutions $(500 \mathrm{mM})$ of the tested samples and DPPH were prepared in DMSO. DPPH solution $(400 \mathrm{mM})$ was added to the sample solution at different concentrations $(500,1000,1500,2000$ and $2500 \mathrm{~mL}$ ) and appropriately diluted with DMSO to a total volume of $4.0 \mathrm{~mL}$. A control was produced by diluting $400 \mu \mathrm{L}$ from DPPH stock solution was also diluted to $4.0 \mathrm{~mL}$ using DMSO solvent. For the control, only solvent was added. Ascorbic acid was used as a standard (using the reference antioxidant) for this test. For the standard, the sample was replaced with the same amount of ascorbic acid. The DPPH radical scavenging method was chosen to assess the antioxidant potential of the target compounds in comparison with the commercially available antioxidant ascorbic acid at the same concentrations. The reaction mixtures were thoroughly mixed by shaking the test tubes vigorously and incubated in a water bath at $25{ }^{\circ} \mathrm{C}$ for 60 min in darkness. Absorbance at $517 \mathrm{~nm}$ was measured and the solvent was corrected throughout. The scavenging effect was calculated using the following equation:

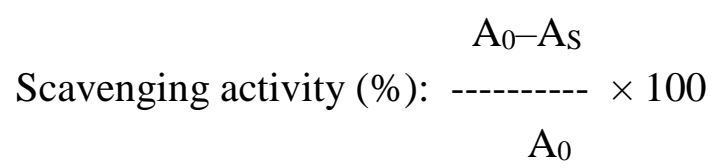

where $A_{S}$ is the absorbance of the DPPH in the presence of the tested compounds and standard and $\mathrm{A}_{0}$ is the absorbance of the DPPH in the absence of the tested compound and standard (control).

Caspase-3 activity. Detection was carried out by means of flow cytometry (Coulter Epics XL), using the Active-Caspase-3 FITC Mab apoptosis kit from Pharmingen, which evaluates the number of cells (\%) that are contained in the dimerized and caspase-3 activated form. Therefore, measurements were taken at 24 and $48 \mathrm{~h}$ and the values obtained were compared with the control cells.

Cell cycle analysis. Cells were plated at a density of $5 \times 10^{5}$ cells/well in six-well plates and they were incubated ovenight at $37{ }^{\circ} \mathrm{C}$ under $5 \% \mathrm{CO}_{2}$. Then, cells were treated with $15 \mu \mathrm{M}$ concentration of the tested compounds for 24 and $48 \mathrm{~h}$. After the incubation period with the compounds, the cells were collected, centrifuged and fixed with ice-cold ethanol (70\%). Cells were stained with $0.5 \mathrm{~g} / \mathrm{L}$ propidium iodide and analyzed using a Coulter Epics XL flow cytometer.

\section{Acknowledgements}

This work was supported by the Ministerio de Ciencia e Innovación (grant SAF 2009-07744) from Spain. E.M. and D.P were recipients of fellowships from the FIMA Foundation and Gobierno de Navarra, Departamento de Educación, respectively. 


\section{References}

1. Ryu, C.K.; Kim, Y.H.; Im, H.A.; Kim, J.Y.; Yoon, J.H.; Kim, A. Bioorg. Med. Chem. Lett. 2012, 22, 500-503.

http://dx.doi.org/10.1016/j.bmcl.2011.10.099

PMid:22113112

2. Modh, R.P.; Patel, A.C.; Mahajan, D.H.; Pannecouque, C.; De Clercq, E.; Chikhalia, K.H. Arch. Pharm. 2012, 345, 964-972.

http://dx.doi.org/10.1002/ardp.201200291

PMid:23018557

3. Chatterjee, N.; Das, S.; Bose, D.; Banerjee, S.; Das, S.; Chattopadhyay, D.; Saha, K.D. Toxicol. Appl. Pharmacol. 2012, 264, 182-191.

http://dx.doi.org/10.1016/j.taap.2012.07.032

PMid:22902631

4. El-Azab, A.S.; Eltahir, K.E. Bioorg. Med. Chem. Lett. 2012, 22, 327-333.

http://dx.doi.org/10.1016/j.bmcl.2011.11.007

PMid:22137344

5. El-Sabbagh, O.I.; Shabaan, M.A.; Kadry, H.H.; Al-Din, E.S. Eur. J. Med. Chem. 2010, 45, 5390-5396.

http://dx.doi.org/10.1016/j.ejmech.2010.08.064

PMid:20850911

6. Rhee, H.K.; Yoo, J.H.; Lee, E.; Kwon, Y.J.; Seo, H.R.; Lee, Y.S.; Choo, H.Y. Eur. J. Med. Chem. 2011, 46, 3900-3908.

http://dx.doi.org/10.1016/j.ejmech.2011.05.061

PMid:21704436

7. Jiang, N.; Zhai, X.; Zhao, Y.; Liu, Y.; Qi, B.; Tao, H.; Gong, P. Eur. J. Med. Chem. 2012, 54, 534-541.

http://dx.doi.org/10.1016/j.ejmech.2012.05.039

PMid:22727449

8. Das, S.; Chatterjee, N.; Bose, D.; Dey, S.K.; Munda, R.N.; Nandy, A.; Bera, S.; Biswas,

S.K.; Das Saha, K. Cell. Physiol. Biochem. 2012, 29, 251-260.

http://dx.doi.org/10.1159/000337606

PMid:22415094

9. Li, D.D.; Fang, F.; Li, J.R.; Du, Q.R.; Sun, J.; Gong, H.B.; Zhu, H.L. Bioorg. Med. Chem. Lett. 2012, 22, 5870-5875.

http://dx.doi.org/10.1016/j.bmcl.2012.07.079

PMid:22901387

10. Al-Rashood, S.T.; Aboldahab, I.A.; Nagi, M.N.; Abouzeid, L.A.; Abdel-Aziz, A.A.; AbdelHamide, S.G.; Youssef, K.M.; Al-Obaid, A.M.; El-Subbagh, H.I. Bioorg. Med. Chem. 2006, $14,8608-8621$. 
http://dx.doi.org/10.1016/j.bmc.2006.08.030

PMid:16971132

11. Zhu, L.H.; Bi, W.; Liu, X.D.; Li, J.F.; Wu, Y.Y.; Du, B.Y.; Tan, Y.H. Oncol. Rep. 2011, 26, 1447-1455.

PMid:21887472

12. Lu, C.C.; Yang, J.S.; Chiang, J.H.; Hour, M.J.; Lin, K.L.; Huang, W.W.; Tsuzuki, M.; Lee, T.H.; Chung, J.G. PloS One 2012, 7, e36831.

http://dx.doi.org/10.1371/journal.pone.0036831

PMid:22662126 PMCid:PMC3360742

13. Zhang, C.; Fan, X.; Xu, X.; Yang, X.; Wang, X.; Liang, H.P. Anticancer Drugs 2010, 21, 766-776.

http://dx.doi.org/10.1097/CAD.0b013e32833d26a9

PMid:20647931

14. Demma, M.; Maxwell, E.; Ramos, R.; Liang, L.; Li, C.; Hesk, D.; Rossman, R.; Mallams, A.; Doll, R.; Liu, M.; Seidel-Dugan, C.; Bishop, W.R.; Dasmahapatra, B. J. Biol. Chem. 2010, 285, 10198-10212.

http://dx.doi.org/10.1074/jbc.M109.083469

PMid:20124408 PMCid:PMC2856225

15. Barraja, P.; Caracausi, L.; Diana, P.; Montalbano, A.; Carbone, A.; Salvador, A.; Brun, P.;

Castagliuolo, I.; Tisi, S.; Dall' Acqua, F.; Vedaldi, D.; Cirrincione, G. ChemMedChem 2011, 6, 1238-1248.

http://dx.doi.org/10.1002/cmdc.201100085

PMid:21574254

16. Kurumurthy, C.; Sambasiva Rao, P.; Veera Swamy, B.; Santhosh Kumar, G.; Santhan Rao, P.; Narsaiah, B.; Velatooru, L.R.; Pamanji, R.; Venkateswara Rao, J. Eur. J. Med. Chem. 2011, 46, 3462-3468.

http://dx.doi.org/10.1016/j.ejmech.2011.05.011

PMid:21632155

17. Ibrahim, D.A.; Ismail, N.S. Eur. J. Med. Chem. 2011, 46, 5825-5832.

http://dx.doi.org/10.1016/j.ejmech.2011.09.041

PMid:22000924

18. Yang, T.; He, H.; Ang, W.; Yang, Y.H.; Yang, J.Z.; Lin, Y.N.; Yang, H.C.; Pi, W.Y.; Li, Z.C.; Zhao, Y.L.; Luo, Y.F.; Wei, Y. Molecules 2012, 17, 2351-2366.

http://dx.doi.org/10.3390/molecules 17032351

PMid:22367029

19. Guo, X.N.; Zhong, L.; Tan, J.Z.; Li, J.; Luo, X.M.; Jiang, H.L.; Nan, F.J.; Lin, L.P.; Zhang, X.W.; Ding, J. Cancer Biol. Ther. 2005, 4, 1125-1132.

http://dx.doi.org/10.4161/cbt.4.10.2024

20. García-Martínez, J.M.; Wullschleger, S.; Preston, G.; Guichard, S.; Fleming, S.; Alessi, D.R.; Duce, S.L. Br. J. Cancer 2011, 104, 1116-1125. 
http://dx.doi.org/10.1038/bjc.2011.83

PMid:21407213 PMCid:PMC3068512

21. Gangjee, A.; Jain, H.D.; Kurup, S. Anticancer Agents Med. Chem. 2008, 8, 205-231. http://dx.doi.org/10.2174/187152008783497064

22. Hashimoto, O.; Shinkawa, M.; Torimura, T.; Nakamura, T.; Selvendiran, K.; Sakamoto, M.; Koga, H.; Ueno, T.; Sata, M. BMC Cancer 2006, 6, 292.

http://dx.doi.org/10.1186/1471-2407-6-292

PMid:17177986 PMCid:PMC1770931

23. Björnstedt, M.; Fernandes, A.P. EMPA J. 2010, 2, 389-395.

24. Abdulah, R.; Kobayashi, K.; Yamazaki, C.; Koyama, H. Int. J. Oncol. 2011, 39, 301-309. PMid:21567081

25. Méplan, C.; Hesketh, J. Mutagenesis 2012, 27, 177-186.

http://dx.doi.org/10.1093/mutage/ger058

PMid:22294765

26. Sanmartín, C.; Plano, D.; Sharma, A.K.; Palop, J.A. Int. J. Mol. Sci. 2012, 13, 9649-9672. http://dx.doi.org/10.3390/ijms13089649

PMid:22949823 PMCid:PMC3431821

27. Cubedo, E.; Cordeu, L.; Bandrés, E.; Rebollo, A.; Malumbres, R.; Sanmartín. C.; Font, M.; Palop, J.A.; García-Foncillas, J. Cancer Biol. Ther. 2006, 5, 850-859. http://dx.doi.org/10.4161/cbt.5.7.2841

28. Cordeu, L.; Cubedo, E.; Bandrés, E.; Rebollo, A.; Sáenz, X.; Chozas, H.; Domínguez, M.V.; Echeverría, M.; Mendívil, B.; Sanmartín, C.; Palop, J.A.; Font, M.; García-Foncillas, J.

Bioorg. Med. Chem. 2007, 15, 1659-1669.

http://dx.doi.org/10.1016/j.bmc.2006.12.010

PMid:17204425

29. Sanmartín, C.; Domínguez, M.V.; Cordeu, L.; Cubedo, E.; García-Foncillas, J.; Font, M.; Palop, J.A. Arch. Pharm. 2008, 341, 28-41.

http://dx.doi.org/10.1002/ardp.200700133

PMid:18161903

30. Font, M.; González, A.; Palop, J.A., Sanmartín, C. Eur. J. Med. Chem. 2011, 46, 3887-3899. http://dx.doi.org/10.1016/j.ejmech.2011.05.060 PMid:21700369

31. Moreno, E.; Plano, D.; Lamberto, I.; Font, M.; Encío, I.; Palop, J.A.; Sanmartín, C. Eur. J. Med. Chem. 2012, 47, 283-298. http://dx.doi.org/10.1016/j.ejmech.2011.10.056 PMid:22104973

32. Plano, D.; Sanmartín, C.; Moreno, E., Prior, C.; Calvo, A.; Palop, J.A. Bioorg. Med. Chem. Lett. 2007, 17, 6853-6859. http://dx.doi.org/10.1016/j.bmcl.2007.10.022 PMid:17964158 
33. Sanmartín, C.; Plano, D.; Domínguez, E.; Font, M.; Calvo, A.; Prior, C.; Encío, I.; Palop, J.A. Molecules 2009, 14, 3313-3338.

http://dx.doi.org/10.3390/molecules14093313

PMid:19783927

34. Plano, D.; Moreno, E.; Font, M.; Encío, I.; Palop, J.A.; Sanmartín, C. Arch. Pharm. 2010, 343, 680-691.

http://dx.doi.org/10.1002/ardp.201000014

PMid:21110339

35. Ibánez, E.; Plano, D.; Font, M.; Calvo, A.; Prior, C.; Palop, J.A.; Sanmartín, C. Eur. J. Med. Chem. 2011, 46, 265-274.

http://dx.doi.org/10.1016/j.ejmech.2010.11.013

PMid:21115210

36. Ibánez, E.; Agliano, A.; Prior, C.; Nguewa, P.; Redrado, M.; González-Zubeldia, I.; Plano, D.; Palop, J.A.; Sanmartín. C.; Calvo, A. Curr. Med. Chem. 2012, 19, 3031-3043.

PMid:22455594

37. Ibánez, E.; Stoedter, M.; Hofmann, P.J.; Plano, D.; Calvo, A.; Nguewa, P.A.; Palop, J.A.;

Sanmartín, C.; Schomburg, L. Metallomics 2012, 4, 1297-1307.

http://dx.doi.org/10.1039/c2mt20096a

PMid:23147262

38. Lamberto, I.; Plano, D.; Moreno, E.; Font, M.; Palop, J.A.; Sanmartín, C.; Encío, I. Curr. Med. Chem. 2013, 20, 1609-1619.

http://dx.doi.org/10.2174/0929867311320120010

39. Pudziuvelyte, E.; Ríos-Luci, C.; León, L.G.; Cikotiene, I. Padrón, J.M. Bioorg. Med. Chem. 2009, 17, 4955-4960.

http://dx.doi.org/10.1016/j.bmc.2009.05.078

PMid:19527934

40. Kassam, S.; Goenaga-Infante, H.; Maharai, L.; Hiley, C.T.; Juliger, S.; Joel, S.P. Cancer

Chemother. Pharmacol. 2011, 68, 815-821.

http://dx.doi.org/10.1007/s00280-011-1649-1

PMid:21519842

41. Facompre, N.D.; Sinha, I.; El-Bayoumy, K.; Pinto, J.T.; Sinha, R. Int. J. Cancer 2012, 131, 2134-2142.

http://dx.doi.org/10.1002/ijc.27468

PMid:22307455

42. Sanmartín, C.; Font, M.; Palop, J.A. Mini Rev. Med. Chem. 2006, 6, 639-650.

http://dx.doi.org/10.2174/138955706777435652

PMid:16787374

43. Mosmann, T. J. Inmunol. Methods 1983, 65, 55-63.

44. Freitas, M.; Alves, V.; Sarmento-Ribeiro, A.B.; Mota-Pinto, A. Biochem. Biophys. Res.

Commun. 2011, 408, 713-719. 
http://dx.doi.org/10.1016/j.bbrc.2011.04.109

PMid:21549092

45. Abdulah, R.; Kobayashi, K.; Yamazaki, C.; Koyama, H. Int. J. Oncol. 2011, 39, 301-309. PMid:21567081

46. Hurst, R.; Hooper, L.; Norat, T.; Lau, R.; Aune, D.; Greenwood, D.C.; Vieira, R.; Collings, R.; Harvey, L.J.; Sterne, J.A.; Beynon, R.; Savovic, J.; Fairweather-Tait, S.J. Am. J. Clin. Nutr. 2012, 96, 111-122.

http://dx.doi.org/10.3945/ajcn.111.033373

PMid:22648711

47. Lukevics, E.; Arsenyan, P.; Shestakova, I.; Domracheva, I.; Kanepe, I.; Belyakov, S.;

Popelis, J.; Pudova, O. Appl. Organomet. Chem. 2002, 16, 228-234.

http://dx.doi.org/10.1002/aoc.276

48. Arsenyan, P.; Rubina, K.; Shestakova, I.; Abele, E.; Abele, R.; Domracheva, I.; Nesterova, A.; Popelis, J.; Lukevics, E. Appl. Organomet. Chem. 2003, 17, 825-830.

http://dx.doi.org/10.1002/aoc.530

49. Arsenyan, P.; Shestakova, I.; Rubina, K.; Domracheva, I.; Nesterova, A.; Vosele, K.;

Pudova, O.; Lukevics, E. Eur. J. Pharmacol. 2003, 465, 229-235.

http://dx.doi.org/10.1016/S0014-2999(03)01529-2

50. Merino-Montiel, P.; Maza, S.; Martos, S.; López, O.; Maya, I.; Fernández-Bola-os, J.G. Eur. J. Pharm. Sci. 2012, 48, 582-592.

http://dx.doi.org/10.1016/j.ejps.2012.12.016

PMid:23287366

51. De Souza Prestes, A.; Stefanello,; S.T.; Salman, S.M.; Pazini, A.M.; Schwab, R.S.; Braga, A.L.; De Vargas Barbosa, N.B.; Rocha, J.B. Mol. Cell. Biochem. 2012, 365, 85-92.

52. Koparir, M.; Orek, C.; Parlak, A.E.; Söylemez, A.; Koparir, P.; Karatepe, M.; Dastan, S.D. Eur. J. Med. Chem. 2013, 63, 340-346.

http://dx.doi.org/10.1016/j.ejmech.2013.02.025

PMid:23517726

53. Simpson, K.L.; Cawthorne, C.; Zhou, C.; Hodgkinson, C.L.; Walker, M.J.; Trapani, F.; Kadirvel, M.; Brown, G.; Dawson, M.J.; Macfarlane, M.; Williams, K.J.; Whetton, A.D.; Dive, C. Cell Death Dis. 2013, 4, e613. http://dx.doi.org/10.1038/cddis.2013.137 PMid:23640455 PMCid:PMC3674346

54. Gulappa, T.; Reddy, R.S.; Suman, S.; Nyakeriga, A.M.; Damodaran, C. Cancer Lett. 2013, 16, S0304-3835.

55. http://www.molinspiration.com/services/properties.html (2012).

56. Kachanov, A.V.; Slabko, O.V.; Baranova, O.V.; Shilova, E.V.; Kaminskii, V.A.; Tetrahedron Lett. 2004, 45, 4461-4463. http://dx.doi.org/10.1016/j.tetlet.2004.04.071 